\title{
DINAMIKA KEJIWAAN TOKOH DALAM NOVEL ASSALAMUALAIKUM CALON IMAM KARYA IMA MADANIAH
}

\author{
Muhammad Ilham \\ SMK Darus Salam Soko Tuban \\ Telp. 085204871412 \\ Email: aamilham189@gamil.Com
}

\begin{abstract}
Abstrak: Penelitian ini bertujuan untuk: Mendeskripsikan perilaku tokoh dan Dinamika Kejiwaan tokoh dalam Novel Assalamualaikum Calon Imam karya Ima Madaniah. Penelitian ini menggunakan metode kualitatif. Metode kualitatif pada penelitian ini berupa: kata-kata, frasa, klausa, dan kalimat pada setiap paragraf. Peneliti menggunakan pendekatan Psikologis Analistik Sigmund Frued. Kehidupan jiwa memiliki tiga kedasaran yakni sadar, prasadar, dan taksadar. Hasil penelitian menunjukkan bahwa perilaku tokoh pada umumnya baik. Dinamika kejiwaan tokoh mengalami naik turun karena faktor internal dan eksternal. Dinamikan kejiwaan Pak Alif semula tidak baik. Ia hampir tidak mengakui adanya Tuhan, pemarah dan frustasi karena berbagai faktor. Perjalanan hidup Pak Alif dari buruk menjadi baik. Dinamika kejiwaan Nafisya mampu mengatasi semua masalah mulai TK sampai Perguruan Tinggi.
\end{abstract}

Kata Kunci: tokoh, perilaku, dinamika kejiwan

\begin{abstract}
This study aims to: Describe the behavior of characters and the Dynamics of Psychology of characters in the novel Assalamualaikum Prospective Imam by Ima Madaniah. This study uses a qualitative method. The qualitative method in this study is: words, phrases, clauses, and sentences for each paragraph. Researchers used Sigmund Frued's Psychological Analytical approach. The life of the soul has three objectives, namely conscious, conscious, and unconscious. The results of the study indicate that character behavior is generally good. The psychiatric dynamics of the character experience a rise and fall due to internal and external factors. The mentality of Mr. Alif was originally not good. He almost did not acknowledge the existence of God, angry and frustrated because of various factors. Mr. Alif's life journey from bad to good. Nafisya psychic dynamics is able to overcome all problems ranging from kindergarten to university.
\end{abstract}

Keywords: character, behavior, social dynamics 


\section{PENDAHULUAN}

Karya sastra ditulis oleh pengarang sebagai pribadi dan anggota masyarakat yang memiliki pengalaman psikologis. Tokoh-tokoh yang ditampilkan pengarang baik langsung maupun tidak, merupakan pengejawantahan psikologis pengarang. Dengan demikian, karya sastra dapat dikaji dari aspek psikologi sastra. Psikologi tokoh tidak lain adalah psikologi pengarang itu sendiri. Psikologi sastra dapat berangkat dari psikologis pengarang dan psikologi tokoh yang ada dalam teks karya sastra tersebut.

Pada dasarnya psikologi sastra memberi perhatian terhadap unsur-unsur kejiwaan tokoh-tokoh fiksional yang terdapat dalam karya sastra. Sebagai dunia dalam karya sastra memasukkan berbagai aspek kehidupan ke dalam karyannya. Khususnya manusia. Aspekaspek kemanusiaan inilah yang merupakan objek utama psikologi sastra, sebab semata-mata dalam diri manusia itulah, sebagai tokoh-tokoh, aspek kejiwaan dicangkokkan dan investasikan. Dalam analisis, pada umumnya menjadi tujuan adalah tokoh utama, tokoh kedua, tokoh ketiga, dan seterusnya.

Analisis psikologi sastra dalam penelitian ini diarahkan untuk mengetahui perilaku dan dinamika kejiwaan tokoh. Ima sebagai pengarang, melalui perilaku tokoh Nafisya dan Pak Alif ingin mempengaruhi masyarakat (pembaca) untuk membangun dan mengubah cara pandang tentang meraih masa depan. Masa depan harus diperjuangkan bukan ditunggu, begitu juga dalam menentukan jodoh harus dipersiapkan segala sesuatunya termasuk ilmu dan amal.

Ada empat alasan peneliti mengambil sumber data penelitian dari novel Assalamualaikum Calon Imam karya Ima Madaniah. Pertama, novel ini mengajak kepada pembaca untuk selalu menjaga kesucian diri. Kedua, novel ini memberikan pelajaran berharga kepada pembaca bahwa membangun rumah tangga perlu persiapan fisik dan batin. Ketiga, novel ini mengajak kepada pembaca untuk selalu mensyukuri nikmat Allah SWT dengan tetap selalu menjalankan perintah-Nya. Keempat, novel ini novel terlaris dan telah dibaca oleh 3 juta kali di tahun 2017 dan akan difilmkan

Perilaku tokoh utama dapat diketahui melalui tuturan kata dalam konteks antarkalimat. Sementara itu, dinamika kejiwaan tokoh dalam melakukan tindakan dapat diketahui melalui penelusuran keadaan jiwa tokoh. Segala perilaku tokoh selalu bersumber pada jiwa 'kesadaran dalam' tokoh. Kesadaran jiwa tokoh dalam karya sastra mendorong untuk melakukan tindakan tertentu. Tindakan-tindakan yang dihasilkan dinamakan perilaku. Berdasarkan perilaku tokoh utama novel Assalamualaikum Calon Imam karya Ima Madaniah ada beberapa tipe, yaitu tipe: religius, pendendam, penyayang, bijaksana, disiplin, suka menolong, dan bertanggung jawab.

\section{METODE PENELITIAN}

Penelitian Psikologi Sastra menggunakan pendekatan kontekstual, yang mengkaji aspek kejiwaan tokoh dalam karya sastra. Aspek kejiwaan yang peneliti maksud adalah Perilaku Tokoh dan Dinamika Kejiwaan Tokoh dalam novel Assalamualaikum Calon Imam karya Ima Madaniah. Teknik penggelolaan data pada penelitian kualitatif di sini yaitu, peneliti itu sendiri yang merupakan subjek dan pelaku langsung yang akan menentukan kualitas rancangan, teori, analisis dan kesimpulan yang tepat. Peneliti melakukan seluruh kegiatan penelitian dengan mengutamakan penalaraan induktif yang dapat dibuktikan (diverifikasi). Peneliti sebagai penentu dalam penelitian 
kualitatif dalam bekerja dibantu dengan alat yang dibuatnya sendiri, yaitu instrumen pengumpulan data yang ditandai dengan kode-kode tertentu supaya mudah dalam mengklasifikasi data.

Instrumen penggelolaan data dibuat sedemikian rupa oleh peneliti sendiri untuk mempermudah dalam melakukan penelitian. Peneliti sebagai subjek penelitian membuat alat penggelolaan data dengan memberikan kode-kode tertentu untuk membedakan data yang akan dibahas. Pada penelitian tesis ini ada dua data yang akan dibahas. Pertama, data yang berkaitan dengan perilaku tokoh. Kedua, data yang berkaitan dengan Dinamika Kejiwaan Tokoh. Dengan demikian dalam penelitian kualitatif ini belum dapat dikembangkan instrumen penelitian sebelum masalah yang diteliti jelas sama sekali. Oleh karena itu, dalam penelitian kualitatif “ the researcher is the key instrumen". Jadi peneliti merupakan intrumen kunci dalam penelitian kualitatif. Peneliti mengunakan korpus data sebagai berikut dalam bekerja. Dinamika Kejiwaan tokoh utama dalam novel Assalamualaikum Calon Imam karya Ima Madaniah. Nafisya Kalia Akbar dan Alif Syaibani Alexis.

Analisis dalam penelitian merupakan cara berpikir yang berkaitan dengan pengujian secara sistematis terhadap sesuatu untuk menentukan bagian, hubungan antarbagian, dan hubungan dengan keseluruhan. Analisis adalah untuk mencari pola. Berdasarkan hal tersebut, maka analisis data adalah proses mencari dan menyusun secara sistematis data yang diperoleh dari hasil wawancara, catatan lapangan, dan dokumentasi, dengan cara mengorganisasikan data ke dalam kategori, menjabarkan ke dalam unit-unit, melakukan sintesa, menyusun ke dalam pola, memilih mana yang penting dan yang akan dipelajari, dan membuat simpulan sehingga dengan mudah dipahami oleh diri sendiri maupun orang lain.

Analisis data kualitatif bersifat induktif, yaitu suatu analisis berdasarkan data yang diperoleh, selanjutnya dikembangkan pola hubungan tertentu yang membentuk hipotesis. Berdasarkan hiporesis pada fokus masalah selanjutnya dicarikan data lagi secara berulang-ulang selanjutnya dapat disimpulkan bahwa berdasarkan data tersebut hipotesis diterima atau ditolak. Bila berdasarkan data yang dikumpulkan secara berulangulang dengan teknik triangulasi, ternyata hipotesis diterima, maka hipotesis tersebut berkembang menjadi teori.

Tahapan analisis ini, merupakan kegiatan utama dan penting, seriring paradigma dan pendekatan kualitatif memang intinya mencari makna dibalik data novel Assalamualaikum Calon Imam Ima Madaniah yang tersurat, dan yang tersirat; yaitu dengan cara mendiskusikan dan mengelaborasi setiap elemen sumber data dengan landasan teori yang digunakan dan menggunakan logika dan intuitif yang dituangkan melalui ekpresi kata-kata. Frase dan kalimat baik berupa penjelasan, sanggahan, penegasan, evaluasi, generalisasi dari data novel Assalamualaikum Calon Imam Ima Madaniah ataupun penyimpulannya.

\section{HASIL PENELITIAN}

\section{Perilaku Tokoh}

Tokoh utama pada novel ini, Nafisya Kaila Akbar dan Alif Syaibani Alexis. Nafisya mempunyai perilaku egois ketika berhadapan dengan lawan jenis. Sebagaimana kutipan berikut. 
"Bulir air mata itu kembali terjatuh. Sungguh, aku tidak ingin menangis lagi karena perasaan konyol ini, terlebih hanya untuk seorang pria. $\mathrm{Aku}$ ingin melupakan Jidan. Bukan kali ini saja. Sudah sejakempat belas tahun lalu aku berencana melupakan perasaan ini. Sayang, semuanya tetap menjadi rencana sampai kami tumbuh dewasa" (Ima, 2018: 9).

Nafisya menganggap Jidan adalah sosok pria yang ideal untuknya. Secara biologis anak perempuan lebih cepat matang daripada anak laki-laki. Gadis yang berusia 14-18 tahun lebih cenderung untuk tidak merasa puas dengan perhatian pemuda yang seusia dengannya. Karena itu ia tertarik kepada pemuda yang usianya berapa tahun di atasnya. Keadaan ini terus berlangsung sampai ia duduk di bangku kuliah. Pada masa itu akan terlihat pasangan mudamudi yang pemudanya berusia lebih tua dari pada gadisnya (Zulkifli, 1986: 66).

Karena itu mempelajari tokoh, memang akan menelusuri jejak psikologisnya. Tokoh juga kadangkadang mempresentasikan psikis pengarangnya. Paling tidak belajar lewat tokoh, pembaca dapat memahami alur psikis pengarang. Penelitian tokoh memang bagian dari aspek intrinsik sastra. Namun, penelitian tokoh yang bernuansa psikis akan berpijak pada psikologis sastra. Gabungan psikologis sastra dan struktur pun juga sah dalam studi sastra (Endraswara, 2008: 179).

Berdasarkan gambaran kalimatkalimat di atas, berarti Nafisya ini mempunyai ego yang kuat. Ia memandang bahwa laki-laki manapun adalah menjijikkan. Oleh karena itu, sebisa mungkin harus dijauhinya tanpa memandang dia siapa dan latar belakang apa. Jika hatinya tidak senang ya tidak senang. Ego sebagai suatu kelompok proses, yaitu proses-proses mengamati, mengingat, dan berpikir, yang perlu untuk membuat dan melaksanakan rencana tindakan untuk mencapai kepuasan sebagai respon terhadap dorongan dari dalam, dan self sebagai cara-cara bagaimana seseorang bereaksi terhadap dirinya sendiri. Self itu mengandung empat aspek, yaitu: 1) bagaimana orang mengamati dirinya sendiri, 2) bagaimana orang berpikir tentang dirinya sendiri, 3) bagaimana orang menilai dirinya sendiri, dan 4) bagaimana orang berusaha dengan berbagai cara untuk menyempurnakan dan mempertahankan diri (Suryabrata, 1982: 249-251).

Sebagai jawaban, mengapa Nafisya begitu ego, berbuat sok terhadap lawan jenis. Tentunya ada sebab yang melatar belakanginya. Nafisya khawatir mengenai keselamatan dari pria tersebut akhirnya ia memaksakan diri untuk mengobatinya agar pria tersebut selamat. Tapi kutipan ini yang menjadi jawabannya: "saya bisa obatin sendiri, Mbak," katanya sambil hendak pergi (Ima, 2018: 27). Ini jawaban dari Nafisya: "Nih, Mas. Lap sendiri aja lukanya. Saya cuman gak suka balas budi. Impas, kan? Assalamualaikum, “ kataku ketus sambil menyerahkan handsock, meninggalkan pria itu sendirian (Ima, 2018: 28).

Alhamdulillah usaha yang dilakukan oleh Nafisya membuahkan hasil, ia sudah bisa menghilangkan nama Jidan, digantikan oleh seorang pria yang bernama Alif Syaibani Alixis, yang berprofesi sebagai dokter dan dosen. Pak Alif ini pernah ditolong oleh Nafisya ketika kecelakaan di jalan, saat ia masih menjadi mahasiswa. Pak Alif ini adalah salah satu dosen Nafisya.

Pak Alif berperilaku tegas dan disiplin, baik ketika menjalankan tugas sebagai dokter dan dosen. Ia memperlakukan semua mahasiswa sama di kampus tidak kecuali Nafisya sang istri. Keluarga yang harmonis, keluarga 
yang menempatkan profisionalisme. Walaupun Nafisya belum bisa memanggilnya dengan panggilan yang mesra untuk suaminya. Ia memanggil dengan panggilan Bapak dan om kepada suaminya. Pak Alif kaya, tetapi ia tetap hidup sederhana. Baginya, kaya harta adalah ujian. Satu hal yang Alif takutkan, yaitu dia tidak bisa mempertanggungjawabkan semuanya di hadapan Allah pada Hari Perhitungan kelak (Ima, 2018: 45). Harta memang titip dari yang Maha Kuasa. Manusia hanya mempunyai hak pakai. Oleh karena itu, kita harus hati-hati dalam mencari dan memanfaatkan.

Sebagai dosen ini adalah sosok pria yang tegas, pandai, dan disiplin sehingga tidak jarang mahasiswa kurang suka kepadanya. Pak Alif tidak toleran kepada mahasiswa yang telat dan tidak mengerjakan tugas. Berikut kutipan "Aturan dalam kelas saya tak jauh berbeda dengan kelas Pak Kevin. Pertama, saya tidak memberi toleransi pada mahasiswa yang datang terlambat, tidak fokus, dan tidak membawa tugas, dan yang kedua..." Dia menuliskan sesuatu di papan tulis (Ima, 2018: 64).

Sebagai seorang suami, Pak Alif adalah sosok pria yang bertanggung jawab terhadap semua kebutuhan keluarga. Memang seharusnya demikian seorang laki-laki dalam rumah tangga. Ia harus bisa menjadi imam bagi dirinya dan anggota keluarga. Oleh karena itu, setiap wanita pasti ingin sukses hidup bersama suaminya, sekaligus mendapatkan limpahan cinta darinya. Sukses hidup dengan suami tidak datang begitu saja, tetapi memiliki beberapa kaidah dan dasar yang harus diikuti dan dijalankan oleh wanita. Sehingga Allah SWT memberikan kesuksesan baginya untuk hidup bersama suaminya serta mendapatkan curahan cinta dan kasih sayangnya.

Allah SWT dan Rasul-Nya SAW telah menjelaskan kaidah, dasar-dasar dan hak-hak yang wajib dia ikuti dan jalankan untuk memperoleh kehidupan rumah tangga yang bahagia selamanya yang dipenuhi dengan kecintaan, kelembutan, dan kasih sayang (AthTharsyah, 2004: 117). Supaya wanita tidak salah pilih, maka pilihlah calon imam yang memiliki akhlah yang baik, pendidikan, dan keluarga yang baik pula.

Fenomena kejiwaan tidak tunggal. Jiwa itu jamak tatarannya. Apabila dikaitkan dengan sastra, jiwa juga berlapis. Lapis-lapis jiwa memang cukup luas hingga sulit dibedakan. Keberadaan jiwa yang bertingkat-tingkat ini justru akan menjadi pemanis sastra. Hal ini karena ekpresi sastra juga akan mengikuti keberadaan jiwa manusia.

Jika dicermati, jiwa manusia itu luas dan dalam. Luas karena mampu mewadahi berbagai hal, dalam karena jiwa menyimpan getaran emosi, konasi, dan kognisi yang sulit dipahami. Dari sini dapat dikatakan bahwa jiwa itu berlapislapis. Tiap lapis mempunyai daya peka yang berbeda. Jiwa manusia mempunyai lima tingkatan.

Bagi pengarang tingkatan-tingkatan itu dapat tercermin dalam karya-karyanya melalui tahapan-tahapan tertentu, yaitu (1) Nivenu anorganis, artinya tingkatan jiwa terendah, sifatnya seperti benda mati. Bila terjelma dalam karya sastra berupa pola, bunyi, irama, baris saja, kalimat, gaya bahasa, dan sebagainya; (2) Neveanu vegetatif, tingkatan kedua, sepertinya tumbuhan, pada tingkat ini telah ada kehidupan, ada gerak, tetapi belum ada perasaan, keinginan dan sebagainya. Bila tingkat ini terjelma dalam karya sastra berupa suasana yang 
ditimbulkan oleh rangkaian kata, misalnya mesra, senang, sedih, dan sebagainya; (3) Neveau animal, tingkatan jiwa seperti yang dimiliki binatang, telah ada hasrat, nafsu, kemauan yang didorong oleh nafsu jasmaniah yang bersifat naluri. Tingkat jiwa ini bila terjelma dalam karya sastra berupa hasrat, keinginan, harapan, cita-cita, dan sebagainya; (4) Niveau Human, tingkatan jiwa ini hanya dapat dicapai oleh manusia berupa perasaan dan akal. Bila terjelma dalam karya sastra, hal ini dapat berupa renungan moral, batin, sikap, pertimbangan pikiran, dan sebagainya; (5) Niveau religius, merupakan tingkatan tertinggi yang tidak dialami manusia sehari-hari, hanya ada saat dalam perenungan. Misalnya, berdoa, bersemedi, meditasi, bila terjelma dalam karya sastra akan berupa hubungan manusia dengan Tuhan (Endraswara, 2008: 22-23).

Pada dasarnya, pengarang memang bukan orang biasa. Pengarang tetap ada level khusus yang tak jelas. Kebanyakan sastrawan juga seorang psikolog. Dia juru jiwa yang memberikan pejelasan efektif dan estetis pada zaman. Jika dipertanyakan apakah novelis sama dengan anak kecil yang "suka ngarang", merekontrusikan pengalaman semaunya sendiri, kadang-kadang untuk menonjolkan diri, jawabanya jelas beda. Atau, apakah pengarang seperti orang yang mengalamu halusinasi mencampuradukkan kenyataan dengan khayalan yang diidam-idamkan atau yang ditakutkannya, jawabannya bisa ya, bisa tidak. Sejumlah novelis termasuk Ima Madaniah menempatkan tokoh-tokohnya sesuai dengan zaman.

\section{Dinamika Kejiwaan Tokoh}

Kepribadian adalah keseluruhan fikiran, perasaan dan tingkah laku, kesadaran dan ketidaksadaran. Kepribadian membimbing orang untuk menyesuaikan diri dengan lingkungan sosial dan lingkungan fisik. Sejak awal kehidupan, kepribadian adalah keseluruhan atau berpotensi membentuk kesatuan. Ketika mengembangkan kepribadian, orang harus berusaha mempertahankan kesatuan dan harmoni antar semua elemen kepribadian (Minderop, 2011: 23-28).

Kepribadian disusun oleh sejumlah sistem yang beroprasi dalam tiga tingkat kesadaran, ego beroprasi pada tingkat sadar. Ego berperan dalam menentukan persepsi, pikiran, perasaan, dan ingatan yang bisa masuk kesadaran. Tanpa seleksi ego, jika manusia akan menjadi kacau karena terbanjiri oleh pengalaman yang semua bebas masuk ke kesadara. Id adalah dorongan untuk memenuhi kebutuhan fisik seperti pemenuhan kebutuhan makan karena adanya adanya stimulus rasa lapar dan selera.

Freud berpendapat manusia sebagai sistem yang komples memakai enerji untuk berbagai tujuan seperti bernafas, bergerak, mengamati, dan mengingat. Kehgiatan psikologik juga membutuhkan enerji, yang disebut enerji psikik ( $p s y c h i c$ energy) enerji yang ditranform dari enerji fisik melalui id beserta instinginstingnya. Ini sesuai dengan kaidah fisik, bahwa enerji tidak dapat hilang, tetapi dapat pindah dan berubah bentuk. Sebagaimana kutipan di bawah ini.

Aku melihat banyak makanan di atas meja. Ada roti isi berbagai selei lengkap dengan tiga gelas susu-punyaku yang berwarna coklat. Satu hal yang membuatku lapar, yaitu ikan balado. Ummi itu hebat makanya kujuluki "queen". Dia salah satu bidadari surga yang ditakdirkan hidup bersamaku di bumi (Ima, 2018: 13).

Untuk memenuhi kebutuhan fisik, Nafisya memakan ikan balado buatan Ummi. Apa yang dimasakkan oleh Ummi, Nafisya suka dan nafsu makannya bertambah. Apalagi ia masih usia remaja, tentu membutuhkan banyak energi untuk 
beraktivitas. Manusia membutuhkan makan untuk menjaga keseimbangan antara jasmani dan rohani. Rohani yang sehat terdapat pada jasmani yang sehat. Di sini Freud berpendapat bahwa ada dua insting hidup dan isnting mati. Insting hidup disebut dengan eros, dorongan yang menjamin survival dan reproduksi, seperti lapar, haus, dan seks. Insting hidup juga disebut dengan libido. Semua tingkah laku yang dimotivasi oleh insting hidup mirip dengan tingkah laku seksual (Alwisol, 2014: 19).

Dalam pandangan fenomenologi, manusia ditakdirkan aneh. Atas keanehan itu, manusia justru menarik dibahas. Dari sisi apapun, termasuk sastra dan psikologi, manusia semakin aneh saja. Fenomena dasar manusia, memang sulit diduga. Kejiwaan manusia kerap tetap, kadang labil. Begitu pula ketika bersentuhan dengan sastra, manusia selalu menunjukkan hal-hal yang di luar kebiasaan (Endraswara, 2008: 17).

Belajar dari sini, fenomena manusia dalam sastra ada dua macam. Manusia riil dan manusia imajinatif tetap memiliki kedudukan yang sama penting. Keduanya tergantung realitas yang membangun makna. Oleh karena itu, jiwa manusia pun memiliki realitas tersendiri dalam sastra. Struktur kejiwaan manusia mengandung dua unsur pokok, yaitu "rasa keakuan kramadangsa" dan 'rasa aku' yang sejati, yang disebut "manusia baru" atau manusia tanpa "ciri" . Di dalam "rasa keakuan Kramadangsa" terkandung dua unsur, yaitu catatandan rasa hidup.

Unsur-unsur kejiwaan manusia mempunyai sifat alamiah tertentu dan mempunyai pola tertentu juga sehingga menentukan gerak rasa manusia. Kejiwaan manusia yang demikian akan mendominasi aspek sastra. Psikologi manusia yang penuh dengan diri akan mencatat pengalaman yang luar biasa.pengalaman tersebut tercurah dalam sastra.

Sekarang Nafisya sudah bisa berpikir dewasa sesuai dengan kematanga usia, pergaulan, dan keadaan lingkungan. Orang yang sadar akan keadaan inilah nantinya yang akan berhasil meraih mimpi-mimpi yang diidamkan. Alhamdulillah Nafisya kuliah sampai lulus. Nafisya, sejak balita sudah ditinggal oleh Abi karena cerai dengan Ummi. Sebagaimana kutipan berikut.

Kak Salysa pulang tiga tahun berikutnya. Kepulangankak salsya membuatku paham bahwa Abi dan Ummi memutuskan bercerai. Walau kak Salsya sudah kembali, ditinggal oleh Abi itu menjadi sebuah trauma, trauma yang tak kunjung sampai sekarang (Ima, 2018: 33).

Biasanya anak yang dilatarbelakangi keluarga broken home, mentalnya labil, trauma yang berkepanjangan, dan sulit dilupakan. Tetapi, tokoh Nafisya ini mempunyai jiwa yang tegar dalam menghadapi cobaan hidup. Semangat membahara demi kebahagiaan masa depan. Ia tidak malu dan putus asa dalam berkuliah demi impiannya. Nafisya, dalam lingkungan kampus banyak teman dari berbagai fakultas. Banyak teman, tentu banyak pula pengalaman yang didapatkan. Baik pengalaman perkuliahan dan pengalaman di luar kuliah, kerja ini itu.

Dinamika kejiwaan Nafisya dan Pak Alif mengalami pasang surut sesuai dengan situasi dan kondisi. Pak Alif sempat marah terhadap ayah angkatnya Pak Azam, sebagaimana kutipan berikut.

"Ayah rindu sama kamu, Lif". Aku bisa merasakan tangan Pak Alif sampai mengepal kuat. Dia 
melepaskan tanganku lalu-Buk! Dia melayangkan tinju ke arah Pak Azzam. (Ima, 2018: 205-206).

Dinamika perjalanan hidup Pak Alif tidaklah mulus begitu saja. Masa lalu Pak Alif bergelimang dengan dosa dan noda. Di kala remaja, waktunya digunakan hura-hura. Pekerjaan terlarang oleh agama dan negara pernah ia langgar. Sebagaimana kutipan di bawah ini.

"Masa lalu saya gak sebaik yang kamu kira, klub malam, DJ, rokok, alkohol, sampai opium pernah saya coba. Saya mantan pecandu, Sya, bahkan saya sempat gak per caya kalau Allah itu ada. Saya dulu belum berani kasih tahu ke kamu semuanya karena saya takut kamu kecewa dengan masa lalu saya". (Ima, 2018: 309).

Pak Alif bukanlah Pak Alif yang masih remaja seperti dulu. Biarkan hidup dulu menjadi kenangan. Tetapi Pak Alif sekarang sudah taubah dan menjadi orang yang diperhitungkan. Sebagaimana kutipan berikut.

"Lihat Pak Alif yang sekarang? Profesor, dokter, hafiz Alquran, dosen juga... Fisya bangga jadi istrinya Pak Alif. Allah kasih kita masa depan karena Allah ngasih kesempatan buat kita perbaiki masa lalu.” (Ima, 2018: 309).

Pak Alif dilahirkan keluarga nonmuslim. Ibunya Maria Alexis, wanita bukan pribumi yang dinikahi orang pribumi. Maria Alexis meninggal ketika mau pulang ke negaranya dan ayah Pak Alif meninggal dalam kecelakaan bus waktu Alif masih SMP. Pak Alif pernah frustasi ketika dalam perjalanan bersama Nafisya istrinya kehabisan bahan bakar. Mereka panik, karena ada janji dengan kelompok belajar. Pak Alif ada solusi menghubungi teman untuk datang dengan membawa bahan bakar untuk mobilnya. Dan, mobil tersebut ditinggal. Pak Alif dan istrinya nunggu lama sekali untuk naik taksi. Taksi tak kunjung datang karena jalan sepi. Mereka melaksanakan salat isyak di masjid terdekat. Setelah salat selesai Pak Alif pesan taksi online.

\section{SIMPULAN DAN SARAN}

Perilaku tokoh Pak Alif dan Nafisya pada umumnya adalah baik. Mereka religius, semangat beribadah dan bekerja sesuai dengan tuntunan agamanya. Waktu mudah digunakan untuk belajar sampai perguruan tinggi walaupun biaya sangat minim. Tokoh Nafisya dan Pak Alif adalah sosok yang patut diajungi jempol karena kegigihan dalam menjalani hidup. Suami istri ini merupakan keluarga idaman remaja masa kini, Nafisya menikah ketika masih berstatus sebagai mahasiswa.

Dinamika kejiwaan tokoh adalah masa naik turunnya keadaan batin/ psikis karena faktor internal dan eksternal. Nafisya, dan Pak Alif tokoh sentral dalam novel tersebut kejiwaannya mengalami naik turun. Pak Alif mengalami liku-liku hidup yang panjang. Ia semula mempunyai kepribadian yang tidak baik menjadi lebih baik, religius, profesor, dan dermawan kepada para dhuafa.

Kegigihan Nafisya dan Pak Alif membuahkan hasil, Nafisya mampu mengatasi masalah walau tidak didampingi Abinya mulai TK sampai Perguruan Tinggi. Pak Alif yatim piatu. Ibunya meninggal ketika mau pulang ke neraga asalnya karena ia bukan orang Indonesia dan nonmuslim. Ayahnya meninggal ketika ia masih duduk di bangku SMP.

Pada penelitian ini ada tiga saran yang akan disampaikan kepada:Pengarang, bahasa yang digunakan banyak menggunakan serapan dari bahasa Arab sehingga para pembaca kesulitan dalam memahami dan menangkap amanat dari pengarang. Novel ini mengungkap tentang perjodohan hanya secara khusus untuk kaum muslimin. Lebih baiknya ditujukan untuk semua kalangan remaja apapun 
latar belakang pendidikan, ras, dan agama demi kehormatan wanita dan bangsa. Pembaca, untuk bisa memahami novel ini dengan benar, maka harus dibaca berulang-ulang dan mengkaitkan unsur intrinsik dengan mengkaitakan dengan ajaran Islam khususnya yang mengantur pergaulan lawan jenis. Sehingga pembaca akan bisa memilih pasangannya sesuai dengan ajaran yang dianut. Peneliti, dapat memperkaya khazanah sastra Indonesia dan membuat peneliti untuk mengapresiasi karya Indonesia yang dikarang oleh sastrawan perempuan muda Indonesia.

\section{DAFTAR RUJUKAN}

Alwisol. 2014. Psikologi Kepribadian. Malang: UMM press.

Endraswara, Suwardi. 2008. Metode Penelitian Psikologi Sastra. Yogyakarta: FBS Universitas Negeri.

Madaniah, Ima. 2018. Assalamualaikum Calon Imam. Jawa Barat: Coconut Books.

Marsanti, Ena Putri, dkk. 2012. Aspek Kejiwaan Tokoh dalam Novel Sebelas Patriot Karya Andrea Hirata. Surakarta: Universitas Sebelas Maret.

Minderop, Albertine. 2011. Psikologi Sastra. Karya Sastra, Metode, Teori, dan Contoh Kasus. Jakarta: Yayasan Pustaka Obor Indonesia.

Moeliono, Anton M. 2007. Kembara Bahasa. Jakarta: Gramedia.

Mulyadi, Budi. 2013. Kondisi Kejiwaan Tokoh Utama "Otoko" dalam Novel Utsukushisa To Kanashimi To Karya Kawabata Yasunari (
Sebuah Kajian Psikoanalisis ) Semarang: Universitas Diponegoro. Prodi Bahasa Indonesia.

Mulyani dan Roni . 2011. Remaja Modern: Unggul dalam IlmuAnggun dalam Akhlak. Bandung: Sidqah Semesta.

Neuman, W. Lawrence. 2013. Metode Penelitian Sosial: Pendekatan Kualitatid dan Kuantitatif. Jakarta: Indeks.

Nurgiyantoro, Burha .2005. Teori Pengkajian Fiksi. Yogyakarta: Gajah Mada University Press.

Ratna, Nyoman Kutha. 2013. Teori, Metode dan Teknik Penilitian Sastra. Yogyakarta: Pustaka Pelajar.

Sariban. 2015. Penelitian Sastra Teori dan Penerapan. Surabaya: Lentera Cendekia.

Sugiyono. 2013. Metode Penelitian Pendidikan Pendekatan Kuantitatif, Kualitatif, dan R\&D. Bandung: Alfabeta.

Tetinsya, Amanda Belina. 2013. Teori Psikologi Sosial, Paper. Makasar: Fakultas Ilmu Komunikasi Fakultas Ilmu Sosial dan Ilmu Politik Universitas Hasanuddin.

Walgito, Bimo. 2004. Psikologi Sosial Suatu Penghantar. Yogyakarta : Andi.

Wulandari, Ayu. 2012. Kondisi Kejiwaan Tokoh Utama dalam Novel Perahu Kertas Karya Dewi Lestari. Semarang: Universitas Diponegoro Fakultas Ilmu Budaya. 2002. Ensklopedi Islam jilid 3. Jakarta: Ichtiar Baru. 
